\title{
Mountain research in UNESCO's Man and the Biosphere Programme: the first five decades
}

\author{
Martin F. Price, Thomas Schaaf \& Maria R. Cárdenas Tomažič
}

Keywords: mountains, biosphere reserves, Man and the Biosphere Programme, UNESCO

\section{Abstract}

Within UNESCO's Man and the Biosphere (MAB) Programme, MAB Project 6 (MAB-6), entitled Impact of human activities on mountain and tundra ecosystems, was initiated in 1971. This paper begins with a history of the activities and key outcomes of MAB-6, which largely comprised national activities within a global framework. From the 1990s, a number of collaborative international projects took place, relating particularly to global change and sacred mountains. The paper ends with brief conclusions.

\section{Introduction}

Within UNESCO's Man and the Biosphere (MAB) Programme, Project 6 (MAB-6), which considered mountain ecosystems and their inhabitants, was initiated in 1971. To a considerable extent, MAB-6 helped to shape Chapter 13, Managing fragile ecosystems: Sustainable mountain development of Agenda 21, agreed in 1992 at the United Nations Conference on Environment and Development. This chapter referred to mountains as important sources of water, energy and biodiversity and other key resources, but as susceptible to erosion, loss of habitats and widespread poverty among mountain people (United Nations 1992, para 13.1). These characteristics and challenges remain true five decades later (e.g., United Nations General Assembly 2019).

The two main sections of this paper, first, provide a brief history of MAB-6, its activities and key outcomes from 1971 to the early 1990s and, second, outline subsequent collaborative international activities in mountain areas within the MAB Programme. The paper ends with conclusions and a look forward.

\section{MAB-6: from 1971 until the early 1990s}

The MAB Programme began in 1971, when its International Coordinating Council (ICC) met for the first time. The ICC stated that the Programme would be "concerned with subjects of global or regional significance" and be interdisciplinary (UNESCO 1971, p.7). Over the previous two years, international experts and the MAB Secretariat had defined 31 possible research themes for the Programme, of which one was $H u$ man adaptation, land-use, and environmental relationships, in extreme environments - including deserts, high mountains, and polar and subpolar regions (Batisse 1971). From these themes, in 1971 the ICC defined 13 (later 14) MAB Projects; number 6 (MAB-6) was on Impact of buman activities on mountain ecosystems (Hadley 2006; UNESCO 1971, 1988). For each project, the ICC outlined the problem: for MAB-6, this was very similar to what was stated 21 years later, in1992, in Chapter 13 of Agenda 21.
MAB-6 built on strong foundations of international and interdisciplinary mountain research (Ives \& Messerli 1990; Ives 2013), and thus developed quite quickly. In January / February 1973, an expert panel met (UNESCO 1973b); and in April, the ICC decided that MAB-6 should be one of four projects "particularly suitable for special attention” (UNESCO 1973a, p. 15). In November, a working group met in Norway. They renamed MAB-6 as Impact of human activities on mountain and tundra ecosystems and outlined a core programme with three problem areas:

1. resource development and human settlement in tropical mountain regions;

2. tourism, technology and land use alternatives in temperate mountains;

3. land use in high-latitude mountain and tundra ecosystems (UNESCO 1973c, p. 18).

They also stressed the need for comparative worldwide research activities.

In 1974, the ICC noted that MAB-6 "had probably received greater and more intensive attention than any other MAB Project" (UNESCO 1974, p. 21) and, a year later, that it "constituted one of the most advanced themes within MAB" (UNESCO 1975, p. 16). The next session of the ICC in 1977 noted that MAB-6 had showed "bealthy progress", with almost 50 activities operational in 19 countries (UNESCO 1977a, p.24); by 1981, there were 85 activities in 31 countries (UNESCO 1981). In 1984, following the Ecology in Practice conference in 1981 (Di Castri et al. 1984) and the first overall assessment of the MAB Programme, the ICC reviewed a progress report on, and proposals for, MAB-6, and stated that "MAB activities concerned with mountain ecosystems [should] remain a priority" (UNESCO 1984b, p. 22).

Information about MAB activities in mountain areas from 1984 onwards is available mainly from UNESCO's InfoMAB newsletter, journal articles and reports. Together with a compilation of titles and other details of field projects (UNESCO 1981), these are the principal sources of the remainder of this section. This presents MAB- 6 activities according to the parts 
Table 1 - MAB-6 projects in the Alps. Source: Price (1995), UNESCO (1981)

\begin{tabular}{|l|l|r|l|}
\hline Country & Area & Years of research & Main theme(s) \\
\hline Austria & Obergurgl & $1971-1980$ & $\begin{array}{l}\text { Systems analysis of an integrated social-ecological system experiencing rapid growth of } \\
\text { tourism }\end{array}$ \\
\cline { 2 - 5 } & Grossglockner & $1973-1980$ & $\begin{array}{l}\text { Structure and function of grassland ecosystems; other environmental and ecological stud- } \\
\text { ies }\end{array}$ \\
\cline { 2 - 5 } & Sameralm & $1973-1983$ & Physical and human geography studies; comparative ecogeographical studies \\
\cline { 2 - 5 } & Gastein & $1977-1985$ & Natural science studies, including impacts of ski areas \\
\hline \multirow{5}{*}{ France } & Briançonnais & $1974-1980$ & Pasture ecosystems, pastoralism, tourism, societal evolution \\
\cline { 2 - 5 } & Aime & $1981-1984$ & Pastures, forests, slope/ soil stability, environmental economics \\
\hline Italy & Adige valley & $1975-1978$ & Anthropization of the environment and remote sensing \\
\hline & Aletsch & $1979-1985$ & Natural science, partly on influences of human activities \\
\cline { 2 - 5 } & Pays d'Enhaut & $1979-1986$ & $\begin{array}{l}\text { Agriculture, forestry, land-use planning, nature protection, demography/economy, tour- } \\
\text { ism, society and the environment }\end{array}$ \\
\cline { 2 - 5 } & Davos & $1981-1986$ & $\begin{array}{l}\text { The biophysical environment and human influences, impacts of tourism; compiled in a } \\
\text { GIS }\end{array}$ \\
\cline { 2 - 5 } & Grindelwald & $1978-1988$ & Natural sciences, agriculture, tourism and its impacts; compiled in a GIS \\
\hline Germany & Berchtesgaden & $1981-1991$ & Ecological problems concerning land use, carrying capacity; integration in a GIS \\
\hline
\end{tabular}

of the world specified in the problem areas, with key references, followed by conclusions.

Activities in temperate and high-latitude mountains

An overview and evaluation of MAB-6 activities in the temperate mountains of Europe and the former USSR was published by Price (1995). Consequently, these activities are only summarized briefly here, based on this book; as the book includes a comprehensive bibliography, references are not provided here. The Alps were a major focus, with major projects in Austria, France, Germany and Switzerland (Table 1), and numerous interactions between scientists involved in the projects. In addition, the Swiss MAB-6 programme produced a number of thematic studies - particularly on agriculture, forestry and tourism - and two syntheses of its overall findings. Also of note is the evolution of modelling approaches, from the Obergurgl project (Austria) to the Swiss projects and the Berchtesgaden project (Germany) (Ives \& Messerli 1990; Price 1995; Scheurer 2020).

In Europe beyond the Alps, MAB-6 activities took place in the Pyrenees, other French mountain ranges, the UK, the Carpathians (Table 2), and in Crimea, and the Caucasus and Urals (Infobox). Although there was considerable research in mountain biosphere reserves (BRs) and within other MAB Projects (e. g., Project 2, on temperate forests) in the former socialist countries, only projects in Poland and the USSR were formally recognized as part of MAB-6 (Price 1995).

Beyond Europe and the USSR, activities also took place in the temperate mountains of Australia, New Zealand (Table 3) and the USA. Activities in the mountains of Colorado (USA) were of particular importance; these included not only meetings (Ives \& Stites 1975), geo-ecological research (Ives 1980) and the production of an environmental atlas (Ives \& Dow 1982), but also the establishment of the International Mountain Society and its journal Mountain Research and Development $(M R D)$ in 1981. This was the first international interdisciplinary peer-reviewed journal on this theme, and it has since published many key papers and proceedings of meetings.

UNESCO (1981) identifies various MAB-6 projects at high latitudes, most in lower-lying areas. Exceptions were projects on land use in northern Sweden and reindeer in Svalbard, Norway (Abrahamsson 1985; Solberg et al. 2001). Subsequently, within the MAB Programme, high-latitude mountains were considered primarily within the Northern Science [later, Sciences] Network, established in 1982, and aligned

Table 2 - MAB-6 projects in other European mountain ranges. Source: Price (1995), UNESCO (1981)

\begin{tabular}{|l|l|r|l|}
\hline Country & Area & Years of research & Main theme(s) \\
\hline \multirow{3}{*}{ Spain } & Western High Aragon (Pyrenees) & $1971-1984$ & Multidisciplinary studies (natural and social sciences), pine forests \\
\cline { 2 - 4 } & & $1976-1990$ & Ecosystems with large herbivores \\
\cline { 2 - 4 } & High Catalan Pyrenees & $1985-1989$ & Land uses, infrastructure, demography; compiled in a GIS \\
\hline \multirow{2}{*}{ UK } & Upland England and Wales & $1975-1982$ & Upland land use; introduced tree species and plantation forestry \\
\hline France & Carpathians & $1976-1983$ & Tourism, reservoirs, land uses \\
\cline { 2 - 4 } & $\begin{array}{l}\text { Causse Méjan (Massif Central) } \\
\text { Pyrotected areas in the Alps, }\end{array}$ & $1981-1992$ & $\begin{array}{l}\text { Development of an observatory of ecological, social and economic } \\
\text { changes }\end{array}$ \\
\cline { 2 - 4 } & Vallée des Duyes (pre-Alps) & $1984-1988$ & Inter-park programme on high-altitude rangelands \\
\cline { 2 - 4 } & Cévennes (Massif Central) & $1984-1993$ & $\begin{array}{l}\text { Production systems linking sheep-raising, diversified plant production, and } \\
\text { forest resources; negotiations for rural management }\end{array}$ \\
\cline { 2 - 4 } & $1991-1993$ & Natural sciences, sustainable development of marginal areas \\
\hline
\end{tabular}


Table 3 - MAB-6 projects in Australia and New Zealand. Source: UNESCO (1981)

\begin{tabular}{|l|l|r|l|l|}
\hline Country & Area & Years of research & Main theme(s) & Key publication \\
\hline \multirow{3}{*}{ Australia } & \multirow{2}{*}{ Snowy Mountains } & $1972-1978$ & Timberlines & Slatyer (1976) \\
\cline { 2 - 5 } & & $1972-1977$ & Utilization of eucalypts & Waugh (1980) \\
\cline { 2 - 5 } & Southern Tablelands & $1977-1982$ & Ecological effects of fire and grazing & Leigh et al. (1987) \\
\hline \multirow{2}{*}{ New Zealand } & Waitaki basin & $1973-1979$ & $\begin{array}{l}\text { Ecological and social aspects of changing resource use } \\
\text { and development }\end{array}$ & O'Connor et al. (1984) \\
\cline { 2 - 5 } & Queenstown & $1977-1980$ & Impacts of tourism & Pearce \& Cant (1981) \\
\hline
\end{tabular}

with MAB Project 3, which focused on grazing lands (Freeman 1983).

Activities in tropical and sub-tropical mountains MAB-6 activities took place in the mountains of 16 countries in Africa, Asia and Latin America (UNESCO 1981). Among these, the only partial regional synthesis is for the Andes (Little et al. 1981), where there were many regional meetings, and a UNESCOUNEP integrated programme (1975-1983). Its first phase was the preparation of a state-of-knowledge report on Andean ecosystems, published as four issues of $M R D$ : vol. 1(2), 2(1), (3), 4(2). The second phase comprised national projects in Argentina, Bolivia, Chile, Colombia, Ecuador and Peru. In 1984, the evaluation of MAB-6 noted that "Reporting on some of (these projects) is well advanced whereas others have only been published in a very limited way to date", and that "the objectives originally set for the national projects had been largely achieved, while acknowledging that problem-solving and application-oriented research is only beginning in the Andean region” (UNESCO 1984b: p. 100, 101). Publications include syntheses of research in Chile (Castro et al. 1984; Fuentes \& Prenafeta 1988), Peru (MAB Peru 1984), and Argentina (Luti 1986). Little et al. (1981) also mention ongoing projects on migration and health in Chile, and migration and population biology in southern Peru.

In Asia, a regional meeting in 1975 considered in tegrated ecological research and training needs in the mountains of south Asia (UNESCO 1977b). One recommendation was to establish a regional institute for integrated mountain development. This was achieved in 1983 with the inauguration of the International Centre for Integrated Mountain Development (ICIMOD) - serving the eight countries of the Hindu KushHimalaya - in Nepal, a country where MAB-6 activities focused particularly on mapping natural hazards (e.g. Kienholz et al. 1984; Zimmermann et al. 1986), with the involvement of scientists from Switzerland and funding from a number of sources, including the UNU as part of its Highland-Lowland Interactive Systems (later, Mountain Ecology and Sustainable Development) project (Ives 2013). In the Indian Himalaya, ecological studies were undertaken in various areas (UNESCO 1981), as well as a project on the impacts of human activities in Sikkim (Bhasin et al. 1984). There were also projects on tourism in the mountains of Iran, on mountain forest steppes in Mongolia, and on ecology and resource management in the northern mountains of Pakistan (UNESCO 1981).

In Africa, there were projects in the late 1970s on the ecology of mountain forests in Burundi, pastoral agriculture in the Atlas of Morocco, and the impacts of human activities on mountain ecosystems in Zaire (UNESCO 1981). However, the first meeting devoted to the African mountains did not take place until 1986, organized by the Commission of Mountain Ecology of the International Geographical Union with support from MAB and UNU. The workshop resulted in the creation of the African Mountains Association, and the proceedings were published as vol. $8(2 / 3)$ and (4) of $M R D$, which include many papers resulting from activities in Ethiopia linked to the MAB Programme. Another project in the 1980s, with support from UNDP, concerned the Mayombe mountains of Central Africa (Sénéchal et al. 1988).

\section{Conclusions}

MAB-6 was an immense catalyst for research in mountains in many parts of the world. Some projects were truly interdisciplinary; most were more narrowly focused. With the exception of Europe and the former USSR, it is often difficult to identify the outcomes in terms of publications. However, publications were not the only outcomes; perhaps at least as important were opportunities for knowledge-exchange and training through many meetings, and the establishment of the International Mountain Society (with MRD) and ICIMOD. The continuing existence of these institutions evidences the recognition by international organizations of the need to collaborate with each other towards sustainable mountain development. Another long-lived example was the UNU project; the MAB Secretariat and other organizations involved in MAB-6 also developed links with FAO, ICSU, IGU, IIASA, IUCN, UNEP (UNESCO 1984b) and IUBS, with which the MAB Programme became a partner in the Comparative studies on tropical mountain ecosystems [TME] programme within the Decade of the Tropics Programme (Monasterio et al. 1987; van der Hammen et al. 1989). It should also be noted that, despite these many international initiatives, the comparative worldwide research activities called for in 1973 did not effectively emerge until the establishment of the Mountain Research Initiative in 2001 (Becker \& Bugmann 2001).

It should also be recognized that research in mountain areas in the first two decades of the MAB Pro- 
Infobox. The key role of MAB-6 in sustainable mountain development in Russia

After the National Committee of the MAB Programme for the USSR gave the Academy of Sciences' Institute of Geography the task of coordinating MAB-6 in the USSR, the Institute established a Mountain Geosystems research laboratory in 1983. This MAB-6 Centre (in Moscow) worked closely with the International Mountain Society, International Geographical Union Commission for High Mountain Geo-ecology and the University of Bern. From 1983 to 1985, regional centres were established, at academic institutes, for the Caucasus (Tbilisi, Georgia), Central Asia (Dushanbe, Tajikistan), the Carpathians-Crimea (L'viv, Ukraine), Altai-Sayan (Barnaul, Altai region), and Baikal (Irkutsk); these centres coordinated research carried out mainly by natural scientists (Price 1995). The MAB-6 Russia group has continued to the present day.

At the global scale, the MAB-6 Centre - with the MAB Programme, the United Nations University (UNU), and the East-West Center (USA) - played a key role by organizing the international conference Transformation of the Mountain Environment (1989) in Tsahkadzor, Armenia. The proceedings were published as issues 11(2) and 12(1) of Mountain Research and Development. The conference also played a significant role in catalysing mountain research and development research in the USSR and, later, Russia and the countries of the Commonwealth of Independent States (CIS). The Centre was also involved in the Bishkek Global Mountain Summit, the concluding event of the International Year of Mountains (2002), and the GLOCHAMORE and GLOCHAMOST projects.

At the regional scale, in 1998, MAB-6 Russia created the concepts of an Altai transboundary BR (China, Kazakhstan, Mongolia, Russia; designated by UNESCO in 2017), and an Altai-Sayan-Baikal mega-corridor of connectivity conservation and development (Badenkov 2010), presented at an international conference in 2010, supported by UNDP, GEF and IUCN, on climate change and biodiversity connectivity conservation in the region.

At the national scale, MAB-6 Russia has made significant contributions to both science (e.g., Kotlyakov et al. 2014) and policy. Activities have included the development of a network of mountain BRs across Russia, as well as:

- 1996-1997: preparing the first national report on Mountain Regions of Russia: State and development problems (Badenkov 1998).

2002: organizing parliamentary hearings on the outcomes of the International Year of Mountains, in association with the Commission of the State Duma (House of Representatives) on sustainable development. These were attended by representatives of most of Russia's mountain regions, and led to the adoption of recommendations to the President, the Parliament and the Government of the Russian Federation, public organizations and the Russian Academy of Sciences.

- 2016: advice to the Government of the Republic of Dagestan, which proposed a Charter of the Mountain Regions of the Russian Federation and a Federal Law On the Development of the Mountain Regions of Russia.

- 2018-2019: expert advice to the Ministry of North Caucasus Affairs and the Institute of Legislation and Comparative Law of the Government of the Russian Federation, leading to a model law Development and Protection of Mountain Territories of the CIS Member States, which was adopted by the Interparliamentary Assembly of Members of the CIS in 2020.

2020: leading consultations on The State strategy for spatial development of the Russian Federation for the period up to 2025 on criteria for the definition of mountain municipalities and the development of measures for the sustainable mountain development of Russia's mountain territories. This was the first time that mountain regions had been included in the State Strategy for Spatial Development, and was the result of nearly 40 years' work by the MAB-6 group.

gramme took place within other MAB Projects - for example, UNESCO (1988) mentions activities relating to arid lands (Project 3), urban areas (Project 11) and, increasingly, in BRs. These included Sierra del Rosario BR (Cuba) (Herrera et al. 1988); Changbaishan BR (China), where a major conference on temperate forests took place in 1986 (Yang et al. 1987); and Krkonoše BR (Czech Republic), where an international conference on monitoring and management took place in 1993 (Flousek \& Roberts 1995). In effect, with the exception of the USSR (Infobox), MAB6 activities gradually ceased in the early 1990s. Subsequently, BRs have been the main focus of both the
MAB Programme as a whole (Reed \& Price 2019) and mountain activities within it.

\section{MAB mountain activities from the 1990 s}

Since the late 1980s, while research has continued within individual mountain BRs (see e.g. Austrian MAB Committee 2011; Borsdorf et al. 2020; Schaaf 2007, 2009), MAB activities in mountain regions have changed from national-level projects within a global framework to international projects, mainly undertaken in collaboration with other organizations. Examples have been the meetings of the African Mountains As- 
Table 4 - Mountain biosphere reserves included in the GLOCHAMORE and GLOCHAMOST projects. Those included in both projects are in bold.

\begin{tabular}{|l|l|}
\hline The Americas & Europe \\
\hline - Mount Arrowsmith and Waterton (Canada) & - Gossenköllesee and Gurgler Kamm (Austria) \\
- Araucarias and Torres del Paine (Chile) & - Berchtesgadener Land (Germany) \\
- Cinturón Andino (Colombia) & $\begin{array}{l}\text { - Sierra Nevada (Spain) } \\
\text { - Lake Torne (Sweden) }\end{array}$ \\
$\begin{array}{l}\text { - Henascarán (Peru) } \\
\text { (USA) }\end{array}$ & $\begin{array}{l}\text { Entlebuch and Swiss National Park (renamed: Val Müstair-Parc } \\
\text { Naziunal) (Switzerland) }\end{array}$ \\
\hline Asia-Pacific & Africa \\
\hline - Kosciuszko (Australia) & - Mount Kenya (renamed Mount Kenya - Lewa) (Kenya) \\
- Changbaishan (China) & - Oasis du Sud (Morocco) \\
- Nanda Devi (India) & - Kruger to Canyons (South Africa) \\
- Issyk-Kul (Kyrgyzstan) & \\
- Uvs Nur Basin (Mongolia) & \\
\hline - Katunskiy, Sikhote Alin and Teberda (Russian Federation) & \\
\hline
\end{tabular}

sociation - in Morocco in 1990, with papers published in vol. 12(4) of MRD; Kenya in 1993; and Madagascar in 1997 (Hurni \& Ramamonjisoa 1999) - as well as many meetings of the IUBS TME programme and at ICIMOD. The MAB Programme was also involved in global initiatives, such as the establishment of the Mountain Forum in 1996 and the Mountain Partnership in 2002 and, in particular, the International Year of Mountains (2002). Mountain BRs have also been an increasing focus of meetings of regional MAB networks and global conferences (e.g., Centre for Mountain Studies 2020). Two major emphases, on global change and on sacred mountains, are described below.

\section{Global change in mountain regions}

Interdisciplinary science has always been a hallmark of the MAB Programme, and the logistic function, including research and monitoring, has been one of the three functions of BRs since the first were established in 1976 - as underlined in successive action plans for BRs (UNESCO 1984a, 2008, 2017). The two most recent - the Madrid and Lima Action Plans - specifically mention climate change, loss of biodiversity, and other aspects of global change as priorities for the MAB Programme. For mountains, this emphasis was foreshadowed by a seminar associated with the EuroMAB meeting in Poland in 1993 (Breymeyer 1995). Subsequently, three global initiatives took place.

\section{GLOCHAMORE}

The Global Change in Mountain Regions (GLOCHAMORE) project (2003-2005) aimed to: (1) develop an integrative research strategy for detecting signals of global environmental change in mountain environments; (2) define the impacts of these changes on mountain regions; and (3) facilitate the development of sustainable resource management regimes for mountain regions. Recognizing that mountain environments - and their people - are particularly prone to the impacts of global change (Huber et al. 2005), mountain BRs were a focus of the project since they include both protected areas with natural or semi-natural environments, where global change impacts can be assessed without direct human disturbance, and non-protected areas, inhabited by people and used economically. Consequently, mountain BRs provide case studies for analysing the response strategies developed by people vis-à-vis global change.

The GLOCHAMORE project was funded by the European Commission under its $6^{\text {th }}$ Framework Programme, with additional resources from the MAB Programme and UNESCO's International Hydrological Programme. Led by the University of Vienna (Austria), the partners comprised 11 universities and research organizations from across Europe and UNESCO. Managers of mountain BRs (Table 4) and over 140 scientists from around the world collaborated in preparing a research strategy for planning and implementing global change research.

Following five international workshops (Lee \& Schaaf, 2004a, b; 2005) and an Open Science Conference (Price 2006), the Mountain Research Initiative published the GLOCHAMORE Research Strategy in 2006 (Björnsen Gurung et al. 2006). This highlights 10 key areas for research needed to guide the sustainable management of mountain regions, particularly in BRs: climate; land use change; the cryosphere; water systems; ecosystem function and services; biodiversity; hazards; health; mountain economies; society and global change. In 2008, at an international workshop at ICIMOD, participants suggested that, ideally, all ten key areas should be implemented for global change research in mountain BRs; however, since developing countries may face financial constraints in doing so, a focus on five key areas was recommended: climate; land use change; water systems; biodiversity; and mountain economies.

\section{GLOCHAMOST}

In the follow-up project to GLOCHAMORE, Global Change in Mountain Sites (GLOCHAMOST) (2009-2011), the GLOCHAMORE Research Strategy was implemented in nine mountain BRs (Table 4). Reports on their activities are available at UNESCO (2020b).

GLOCHAMORE and GLOCHAMOST were among the MAB Programme's first research projects which specifically addressed global change in BRs. Us- 
ing an interdisciplinary and intercontinental approach, and applying a comparative methodology through the resulting research strategy, the two projects generated a wealth of scientific information that can be used for effective management of mountain BRs in the face of global change. Several initiatives that were started by the projects continue, such as the Sierra Nevada Observatory for Monitoring Global Change in Spain's Sierra Nevada BR (Zamora Rodríguez et al. 2016).

\section{Climate change and ecosystem services}

A further project focusing on mountain areas, Climate Change Impacts in Major Mountainous Regions of the World: Multidisciplinary Network for Adaptation Strategies (Africa, Asia, Latin America and Europe), took place in 2013-2014. Unlike the GLOCHAMORE and GLOCHAMOST projects, it did not have a specific focus on mountain BRs. The project was organized by the International Hydrological Programme and MAB in cooperation with UNEP, ICIMOD and the Mountain Partnership Secretariat at FAO. The final report (Egan \& Price 2017) presents a review of potential climate change and anthropogenic pressures on mountain ecosystem services (ES), particularly in relation to water resources scarcity and increasing water demand resulting from rapid increases of population and utilization of mountain ES. While the report takes a global perspective, it also analyses how regional specificities may differentially affect mountain ES in different mountain systems. The report concludes with recommendations on future policy directions to support adaptation measures, specifically for mountain ES, using an ecosystem-based approach.

\section{Sacred mountains and biosphere reserves}

According to traditional worldviews in Africa, Asia and Latin America, many mountain BRs contain sacred natural sites. Their roles in conserving biological diversity and ensuring cultural integrity were the objective of a MAB research initiative from 1997 to 2005. Studies on the interrelationships of environmental conservation and cultural expressions focused on mountain BRs - e. g. Uluru (Australia), Changbaishan and Xishuangbanna (China), Sierra Nevada de Santa Marta (Colombia), Boghd Khan Uul (Mongolia), Huascarán (Peru), and Hawaiian Islands (USA) - as well as sacred natural sites in non-mountain BRs. International workshops in India, Japan, Mongolia, Peru and the USA further elucidated this topic and culminated in an international symposium in Tokyo, organized by UNESCO and UNU, with partners including FAO, IUCN and the CBD (Schaaf \& Lee 2006).

\section{Conclusions and prospective}

MAB activities in mountain areas have been a major - and often leading and innovative - element of the MAB Programme and, indeed, of mountain science, for nearly half a century. Since the conclusion of the projects described in the previous section, a workshop on mountain BRs took place at the $4^{\text {th }}$ World Congress on BRs in Lima, Peru, in 2016 (UNESCO 2020a). This recognized that there has been, and still is, much ongoing research within mountain BRs, particularly on biophysical aspects (including climate change), but that research related to socio-economic aspects needs to be strengthened. The participants recommended that a network should be established to exchange information and experiences and undertake collaborative work, including between the universities working in and with mountain BRs, in order to achieve synergies in relation to research and monitoring, and management for decision and policymaking, especially in relation to the provision of ecosystem services. Discussions to these ends are ongoing, and the MAB Programme is launching the World Network of Mountain BRs in 2021 to mark its $50^{\text {th }}$ anniversary. It will be desirable that - in addition to interdisciplinary science as promoted by MAB- 6 in the past - transdisciplinary science should shape future MAB activities in mountain areas. This is particularly relevant with regard to BRs, as they foster not only biodiversity conservation, particularly in their core areas and buffer zones, but also sustainable development, especially in their transition areas, for the benefit of mountain people and hundreds of millions more.

\section{Acknowledgements}

The Infobox is based on information provided by Yuri Badenkov (Founder and Leader of the MAB-6 Mountain Group at the Institute of Geography, Russian Academy of Sciences, 1983-2013) and Alexey Gunya (Senior Scientist, Leader of the MAB-6 Group since 2013).

\section{References}

Abrahamsson, K.V. (ed.) 1985. Northern Land Use and Grazing Animals. Umeå.

Austrian MAB Committee (ed.) 2011. Biosphere Reserves in the Mountains of the World: Excellence in the Clouds? Vienna.

Badenkov, Y. 1998. Mountain regions of the European Russia: Status and problems. Ambio 27(4): 361368.

Badenkov, Y. 2010. Altai Mountain Knot: Between conservation and development. In: Worboys, G.L., W.L Francis \& M. Lockwood (eds.), Connectivity Conservation Management. A Global Guide: 246-250. London.

Batisse, M. 1971. Man and the Biosphere: An international research programme. Environmental Conservation 4(1): 1-6.

Becker, A. \& H. Bugmann (eds.) 2001. Global Change and Mountain Regions: The Mountain Research Initiative. IGBP Report Series 49; GTOS 28; IHDP Report Series 13 . Stockholm. 
Bhasin, M.K., V. Kumar \& A. Sehgal 1984. Impact of human activities on the ecosystem and vice-versa with reference to the Sikkim-Himalaya MAB (Man and Biosphere) Program, UNESCO. Mountain Research and Development 4: 267-271.

Björnsen Gurung, A. (ed.) 2006. Global Change and Mountain Regions Research Strategy. Zurich.

Borsdorf, A., V. Braun, K. Heinrich \& M. Jungmeier (eds.) 2020. Biosphäre 4.0: UNESCO-Biosphärenparks als Modellregionen einer nachhaltigen Entwicklung.

Bouamrane, M., P. Dogsé \& M.F. Price 2019. Biosphere reserves from Seville, 1996, to building a new world for 2030: A global network of sites of excellence to address regional and global imperatives. In: Reed, M.G. \& M.F. Price (eds.), UNESCO Biosphere Reserves: Supporting Biocultural Diversity, Sustainability and Society: 29-44. Abingdon \& New York.

Breymeyer, A. (ed.) 1995. EURO-MAB IV: Mountain Zonality facing Global Change. Warsaw.

Castro, M., A. Veloso \& E. Bustos 1984. The Chilean altiplano: Natural environment and socio-cultural traits of the Aymara population. In: di Castri, F., F.W.G. Baker \& M. Hadley (eds.) Ecology in Practice 2: 212-217. Paris.

Centre for Mountain Studies 2020. Global change and the world's mountains: Extended abstracts. Available at https://www.perth.uhi.ac.uk/t4-media/one-web/perth/ subject-areas / mountain-studies/events/previousevents/perth-ii-global-change-and-the-worlds-mountains/extendedabstracts.pdf (accessed: 22/09/2020)

di Castri, F., F.W.G. Baker \& M. Hadley (eds.) 1984. Ecology in Practice. Paris.

Egan, P. \& M.F. Price 2017. Mountain Ecosystem Services and Climate Change: A Global Overview of Potential Threats and Strategies for Adaptation. Paris.

Flousek, J. \& G.C.S. Roberts (eds.) 1995. Mountain National Parks and Biosphere Reserves: Monitoring and Management, V rchlabi.

Freeman, M.M.R. 1983. An international network for cooperation in northern science. Polar Record 21(135): 603-605.

Fuentes, E. \& S. Prenafeta (eds.) 1988. Ecología del Paisaje en Chile Central. Santiago.

Hadley, M. 2006. A practical ecology: The Man and the Biosphere (MAB) Programme. In: Petitjean, P., V. Zharov, G. Glaser, J. Richardson, B. de Padirac \& G. Archibald (eds.), Sixty Years of Science at UNESCO 1945-2005: 260-296. Paris.

Herrera, R.A., L. Menéndez, M.E. Rodríguez, E.E. García (eds.) 1988. Ecologia de los Bosques Siempreverdes de la Sierra de Rosario, Cuba. Montevideo.

Huber, U.M., H.K.M. Bugmann, M.A. Reasoner (eds.) 2005. Global Change and Mountain Regions: An Overview of Current Knowledge. Dordrecht.

Hurni, H. \& J. Ramamonjisoa (eds.) 1999. African Mountain Development in a Changing World. Antananarivo and Bern.
Ives, J.D. (ed.) 1980. Geoecology of the Colorado Front Range: A Study of Alpine and Subalpine Environments. Boulder.

Ives, J.D. 2013. Sustainable Mountain Development: Getting the Facts Right. Lalitpur.

Ives, J.D. \& V. Dow 1982. A mountain environmental atlas: The Indian Peaks area, Colorado Front Range, U.S.A. Mountain Research and Development 2: 337-348.

Ives, J.D. \& B. Messerli 1990. Progress in theoretical and applied mountain research, 1973-1989, and major future needs. Mountain Research and Development 10: 101-127.

Ives, J.D. \& A. Stites 1975. Program on Man and the Biosphere (MAB) Project 6: Impact of human activities on mountain and tundra ecosystems. Proceedings of the Boulder workshop, July 1974. Boulder.

Kienholz, H., G. Schneider, M. Bichsel, M. Grunder \& P. Mool 1984. Mountain hazards mapping projects, Nepal: Base map and map of mountain hazards and slope stability, Kathmandu-Kakani area. Mountain Research and Development 4: 247-266.

Kotlyakov, V.M., Y.P. Badenkov \& K.V. Chistyakov (eds.) 2014. Mountain research. Mountain Regions of Northern Eurasia in Global Change Conditions. Moscow (in Russian)

Lee, C. \& T. Schaaf (eds.) 2004a. Global Change Research in Mountain Biosphere Reserves. Paris.

Lee, C. \& T. Schaaf (eds.) 2004b. Global Environmental and Social Monitoring. Paris.

Lee, C. \& T. Schaaf (eds.) 2005. Global Change Impacts in Mountain Biosphere Reserves. Paris.

Leigh, J.H., D.J. Wimbush, D.H. Wood, M.D. Holgate, A.V. Slee, M.G. Stanger \& R.I. Forrester 1987. Effects of rabbit grazing and fire on a sub-alpine environment. I. Herbaceous and shrubby vegetation. Australian Journal of Botany 35: 433-464.

Little, M.A., P.T. Baker \& J.D. Ives 1981. Planning and development of MAB research in the Andes. Mountain Research and Development 1: 103-114.

Luti, R. (ed.) 1986. Programa de investigacion integrada y entrenamiento en la region andina y montañas extra-andinas: Volumen de sintesis. Montevideo.

MAB Peru 1984. Estudio ambiental de la unidad de produccion alto andina, "Sais Ramon Castilla", Departamento de Junin. Lima.

O’Connor, K., E.J. Costello \& I.G.C. Kerr 1984. Pastoral production and grassland conservation in the Waitaki, New Zealand: an appraisal of their role in a river basin approach for land use planning. In: di Castri, F., F.W.G. Baker \& M. Hadley (eds.), Ecology in Practice 1: 344-367. Paris.

Pearce, D.G. \& R.G. Cant 1981. The development and impact of tourism in Queenstown. New Zealand MAB Report No.7. Lincoln.

Price, M.F. 1995. Mountain Research in Europe: An overview of $M A B$ Research from the Pyrenees to Siberia. Paris \& Carnforth.

Price, M.F. (ed.) 2006. Global Change in Mountain Regions. Duncow. 
Price, M.F., T. Arnesen, E. Gloersen \& M.J. Metzger 2018. Mapping mountain areas: Learning from global, European and Norwegian experiences. Journal of Mountain Science 15: 1-15.

Reed, M.G. \& M.F. Price (eds.) 2019. UNESCO Biosphere Reserves: Supporting Biocultural Diversity, Sustainability and Society. Abingdon \& New York.

Schaaf, T. 2007. Herausforderungen des globalen Umweltwandels - Internationale wissenschaftliche $\mathrm{Zu}$ sammenarbeit mit Hilfe der Gebirgsbiosphärenreservate. UNESCO heute 2007(2): 31-33.

Schaaf, T. 2009. Mountain Biosphere Reserves - A people-centred approach that also links global knowledge. Sustainable Mountain Development 55: 13-15.

Schaaf, T. \& C. Lee (eds.) 2006. Conserving Cultural and Biological Diversity: The Role of Sacred Natural Sites and Cultural Landscapes. Paris.

Scheurer, T. 2020. Das MAB-6 Projekt der UNESCO: Von der Ökosystemforschung zum MAB Biosphere Reserve. In: Borsdorf, A., V. Braun, K. Heinrich \& M. Jungmeier (eds.), Biosphäre 4.0. - UNESCO-Biosphärenparks als Modellregionen einer nachhaltigen Entwicklung: 86-98.

Sénéchal, J., M. Kabala \& F. Fournier (eds.) 1988. Revue des Connaissances sur le Mayombe. Paris.

Slatyer, R.O. 1976. Water deficits in timberline trees in the Snowy Mountains of South-Eastern Australia. Oecologia 24: 357-366.

Solberg, E.J., P. Jordhøy, O. Strand, R. Aanes, A. Loison, B.-E. Sæther \& J.D.C. Linnell 2001. Effects of density-dependence and climate on the dynamics of a Svalbard reindeer population. Ecography 24: 441-451.

UNESCO 1971. International Co-ordinating Council of the Programme on Man and the Biosphere (MAB): First session. Final report. Paris.

UNESCO 1973a. International Co-ordinating Council of the Programme on Man and the Biosphere (MAB): Second session. Final report. Paris.

UNESCO 1973b. Programme on Man and the Biosphere (MAB): Expert panel on Project 6: Impact of human activities on mountain ecosystems. Paris.

UNESCO 1973c. Programme on Man and the Biosphere (MAB): Working group on Project 6: Impact of human activities on mountain and tundra ecosystems. Paris.

UNESCO 1974. International Co-ordinating Council of the Programme on Man and the Biosphere (MAB): Third session. Final report. Paris.

UNESCO 1975. International Co-ordinating Council of the Programme on Man and the Biosphere (MAB): Fourth session. Final report. Paris.

UNESCO 1977a. International Co-ordinating Council of the Programme on Man and the Biosphere (MAB): Fifth session. Final report. Paris.

UNESCO 1977b. Regional meeting on integrated ecological research and training needs in the southern Asian mountain systems, particularly the Hindu Kush-Himalayas. Paris.

UNESCO 1981. MAB Field Projects (Phase I). Paris.

UNESCO 1984a. Action plan for biosphere reserves. Nature and Resources 22(4): 11-22.
UNESCO 1984b. International Co-ordinating Council of the Programme on Man and the Biosphere (MAB): Eighth session. Final report. Paris.

UNESCO 1986. International Co-ordinating Council of the Programme on Man and the Biosphere (MAB): Ninth session. Final report. Paris.

UNESCO 1988. Man Belongs to the Earth. Paris.

UNESCO 2008. Madrid Action Plan for Biosphere Reserves (2008-2013). Paris.

UNESCO 2017. Lima Action Plan for UNESCO's Man and the Biosphere (MAB) Programme and its World Network of Biosphere Reserves (2016-2025). Paris.

UNESCO 2020a. Fourth World Congress on Biosphere Reserves. Mountains workshop. Available at: http://www. unesco.org/new/en/natural-sciences/environment/ ecological-sciences/4th-world-congress/workshopsand-side-events/workshops/mountains-workshop/ (accessed: 22/09/2020)

UNESCO 2020b. Global and climate change in mountain sites. Available at: http://www.unesco.org/new/en/ natural-sciences/environment/ecological-sciences/ specific-ecosystems/mountains/glochamost/ (accessed: 21/09/2020).

UNESCO 2020c. World Network of Biosphere Reserves. Available at: https://en.unesco.org/biosphere/wnbr (accessed: 29/09/2020)

United Nations 1992. Agenda 21. New York.

United Nations General Assembly 2019. Sustainable mountain development: Report of the Secretary-General. Document A/74/209. New York.

Van der Hammen, T., D. Mueller-Dombois \& M.A. Little (eds.) 1989. Manual of methods for mountain transect studies. Paris.

Waugh, G. 1980. The potential of plantation eucalypts for saw-log production. In: Australian and New Zealand Institute of Foresters Conference. Rotorua.

Yang, H., W. Zhan, J.N.R. Jeffers \& P.A. Ward (eds.) 1987. The Temperate Forest Ecosystem. Grange-over-Sands.

Zamora Rodríguez, R.J., A.J. Pérez Luque, F.J. Bonet García, J.M. Barea Azcón \& R. Aspizua Cantón (eds.) 2016. Global Change Impacts in Sierra Nevada: Challenges for Conservation. Sevilla.

Zimmermann, M., M. Bichsel \& H. Kienholz 1986. Mountain hazards mapping in the Khumbu Himal, Nepal. Mountain Research and Development 6: 29-40.

\section{Authors}

Martin F. Price - corresponding author established the Centre for Mountain Studies, Perth College, University of the Highlands \& Islands (Scotland, UK) in 2000, and was appointed Chairholder of the UNESCO Chair in Sustainable Mountain Development in 2009. He has had many roles in the MAB Programme. Centre for Mountain Studies, Perth College, University of the Highlands \& Islands, Crieff Road, Perth PH1 2NX, United Kingdom. E-mail: martin.price.emeritus@uhi.ac.uk 


\section{Thomas Schaaf}

a geographer, advises governments on the creation of biosphere reserves and is guest lecturer at Freiburg University, Germany. From 1987 to 2013, he worked at the MAB Secretariat in Paris, where he was in charge of dryland and mountain ecosystems. Terra-Sana environmental consulting, Guenterstralstr. 12A, D-79100 Freiburg, Germany. E-mail: t.schaaf@terra-sana.org

\section{Maria R. Cárdenas Tomažič}

a geographer from the Pontificia Universidad Católica, Chile, is studying for a Master's degree in Sustainable Development at the University of Sussex (UK) and works as Associate Programme Specialist in the MAB Secretariat. Man and the Biosphere Programme, Division of Ecological and Earth Sciences, UNESCO, 7, place de Fontenoy, F-75352 Paris 07 SP, France. E-mail: m.cardenas@unesco.org 